\title{
KELOR (Moringa oleifera Lam.): PEMANFAATAN DAN BIOAKTIVITAS
}

\author{
Endang Christine Purba
}

Puri Kintamani Blok C6/8, Cilebut, Bogor, Jawa Barat, Indonesia

*Corresponding author: endang.christine@yahoo.com

\begin{abstract}
Moringa oleifera Lam. (MO) is one of the plants that has been widely known its use by Indonesians which is called Kelor. MO belongs to Moringaceae family. Kelor is a useful plant that widely used as medicinal plants and edible food that it is called as an Amazing Tree dan The Miracle Tree. Moringa oleifera has several pharmacological potentials, which are anti-microbial, antioxidant, nutritional food, anti-cancer and anti-diabetic. The writing of this article collects information on the use of ethnobotanical Moringa oleifera plants and the results of their test content. It is hoped that this information would become information to determine the other potential of Moringa oleifera as a source of both traditional and modern medicines.
\end{abstract}

Keywords: amazing tree, moringa tea, anti-diabetic, malnutrition, anti-cancer

\section{PENDAHULUAN}

Kelor (Moringa oleifera atau MO) merupakan tumbuhan yang diakui memiliki banyak kegunaan secara nasional dan internasional. Di Indonesia MO digunakan untuk pemenuhan pangan, obat-obatan, bahan kosmetik dan ritual adat budaya (Bahriyah et al., 2015; Liyanti et al., 2015; Hardiyanthi, 2015; Kholis \& Hadi, 2010). Tercatat bahwa MO digunakan untuk mengobati demam, sawan, batuk, penambah stamina, kejang-kejang, panas dalam, sakit kepala, kolestrol, gizi buruk, asam urat, kencing manis, gondok, kuning, rematik, pegel linu dan tipus (Bahriyah et al., 2015; Oktafiani, 2018). Masyarakat Sampang Madura menggunakan MO dalam acara yang berkaitan adat dan budaya yaitu bahan sesajen, penghilang pengasihan, pemandian mayat, proses kelahiran dan ritual pagut (Bahriyah et al., 2015).
Masyarakat Guatemala memanfaatkan MO untuk menyembuhkan penyakit infeksi pada kulit, mukosa, demam, flu, masuk angin, gangguan pencernaan, dan rematik (Caceres et al., 1991, Caceres et al., 1991b). Masyarakat Bangladesh membuat ramuan MO untuk mengobati diabetes mellitus, sembelit, gangguan pencernaan, dan edema (Kadir et al. 2012, Islam et al. 2014). Kulit dan daun MO dimanfaatkan untuk mengobati diare di Nigeria (Adamu et al. 2005). Masyarakat India menggunakan untuk mengobati gangguan peranakan, kontrasepsi perempuan, jantung, obat cacing, penurun panas (antipiretik), antiparalitik, penyakit sembelit, darah tinggi, anemia kulit, dan bahan kosmetik (Saikia, 2006; Sivasankari et al., 2014; Yabesh et al., 2014). Masyarakat Zimbabwe memanfaatkan daun MO untuk mengobati diare dan sakit gigi (Maroyi 
2013). Masyarakat di Afrika Barat menggunakan sebagai anti malaria (Yetein et al., 2013).

Bagian tumbuhan MO yang sering dimanfaatkan di Indonesia adalah daun. Daun biasanya digunakan untuk makanan, obat tradisional, dan bahan ritual adat. Salah satu pemanfaatan daun untuk pengobatan penyakit kuning yaitu dengan meminum ramuan daun kelor yang ditumbuk halus, ditambah air kelapa, disaring, dan ditambahkan madu (Oktafiani, 2018). Tercatat bahwa daun MO mengandung vitamin A lebih banyak dari wortel, lebih banyak kalsium dari susu, lebih banyak zat besi dari bayam, lebih banyak vitamin $\mathrm{C}$ dari jeruk dan lebih banyak potassium dari pisang (Mutiara et al., 2012). Pemanfaatan akar untuk mengobati penyakit gondok, kolesterol, batuk, demam, asam urat, kencing manis dan sawan (Bahriyah et al., 2015). Batang MO digunakan untuk pakan ternak, obat sakit perut, batuk dan demam (Bahriyah et al., 2015). Buah MO biasanya digunakan sebagai sayuran (Bahriyah et al., 2015). Bijinya digunakan untuk mengobati sakit perut (Bahriyah et al., 2015). Banyaknya manfaat MO dalam kehidupan manusia menjadikan MO sebagai tumbuhan dengan julukan sebagai Amazing Tree dan The Miracle Tree.

Walaupun dikenal sebagai tumbuhan bermanfaat, masih sedikit masyarakat Indonesia yang belum memanfaatkan sebagai sumber pangan. Pemanfaatan MO lebih banyak dimanfaatkan sebagai bahan ritual dan pakan ternak. Hal tersebut disebabkan oleh adanya aroma langu yang kuat pada daun kelor (Becker, 2003) serta rasa pahit, getir dan pedas (Qoniah, 2014). Selain mengandung $\beta$-karoten, protein, vitamin $\mathrm{C}$, kalsium dan potassium, daun MO mengandung tannin, flavonoid, saponin, antarquinon, alkalaoid dan kuersetin (Dillard \& German 2003, Waldron et al., 2003; Kasolo et al., 2010; Sutrisno, 2011). Hal tersebut menyebabkan MO mengandung antioksidan di mana kandungannya melebihi sebanyak tujuh kali vitamin C (Fuglie, 2001). Informasi yang sudah disebutkan sebelumnya menjadi alasan menarik untuk mengetahui kandungan bioaktivitas Moringa oleifera sehingga dapat mengembangkan pemanfaatannya lainnya. Oleh karena itu, artikel ini diharapkan dapat menjadi sumber informasi untuk pengembangan Moringa oleifera sebagai bahan pangan, obat tradisional dan rencana pengembangannya.

\section{METODE PENELITIAN}

Adapun data yang digunakaan dalam penulisan artikel ini diperoleh melalui metode studi pustaka secara online dan offline. Penelusuran pustaka online melalui Google Scholar dan beberapa jurnal ilmiah dengan menggunakan kata kunci yang berhubungan dengan penulisan artikel ini, 
misalnya Moringa oleifera, etnobotani Moringa oleifera, pemanfaatan Moringa oleifera dan bioaktivitas Moringa oleifera. Selanjutnya data yang diperoleh kemudian dianalisis dan disintesis, serta disusun untuk memperoleh informasi tentang kandungan dan pemanfaatan Moringa oleifera.

\section{HASIL DAN PEMBAHASAN}

\section{Botani Kelor (Moringa oleifera)}

Kelor (Moringa oleifera) berasal dari India utara dan saat ini dapat ditemukan di daerah tropis (Mutiara et al., 2012). Tumbuhan ini dikenal dengan berbagai nama, yaitu horseradish tree, drumstick tree, benzolive, miracle tree, magic tree, marango, mlonge, moonga, mulangay, nébéday, saijhan, sajna atau Ben oil tree (Awodele et al., 2012, Mutiara et al., 2012). Kelor merupakan tumbuhan yang sangat mudah ditemukan di Indonesia dan biasanya tumbuh sebagai tanaman pagar di pekarangan rumah khususnya di wilayah non-urban. Masyarakat Sulawesi mengenalnya dengan sebutan kero, wori, kelo atau keloro; maronggih di Madura; murong di Aceh; kelor di masyarakat Sunda dan Melayu; kelo di Ternate; munggai di Sumatra Barat dan kawona di Sumbawa (Krisnadi, 2010).

Kelor (Moringa oleifera) termasuk dalam Family Moringaceae. Moringaceae merupakan Family monogeric dengan satu genus yaitu Moringa yang memiliki 33 species, di mana 4 (empat) species berstatus diterima, 4 (empat) species adalah sinonim dan 25 species belum terverifikasi (Mabberley, 1987). Dari jumlah species yang sudah disebutkan diatas, sebanyak 13 species berasal dari daerah tropis (Olson, 2002). Walaupun hampir semua species Moringa berasa dari India dan Afrika, saat ini sudah tersebar ke beberapa negara tropis termasuk beberapa negara, yaitu Madagaskar, Namibia, Angola, Kenya, Etiopia, Pakistan, Banglades dan Afghanistan (Fahey, 2005; Amaglo et al., 2010).

Menurut Olson (2002), akar pada saat muda memiliki bonggol yang akan berubah menjadi kayu pada saat tua. Moringa oleifera merupakan tumbuhan yang berhabitus pohon yang selalu berdaun (evergreen) yang mencapai tinggi 10-12 m (Gambar 1a) (Arora et al., 2013). Batang MO berkayu, permukaan kasar, percabangan sympodial, tumbuh lurus dan memanjang (Winarno, 2018). Kulit batang MO berwarna abu-abu yang pucat atau cokelat, halus atau halus berkerut (Olson, 2002). Daun MO berwarna hijau, merupakan daun majemuk bertangkai Panjang yang tersusun berseling, imparipinatus (Gambar 1b) (Winarno, 2018). 

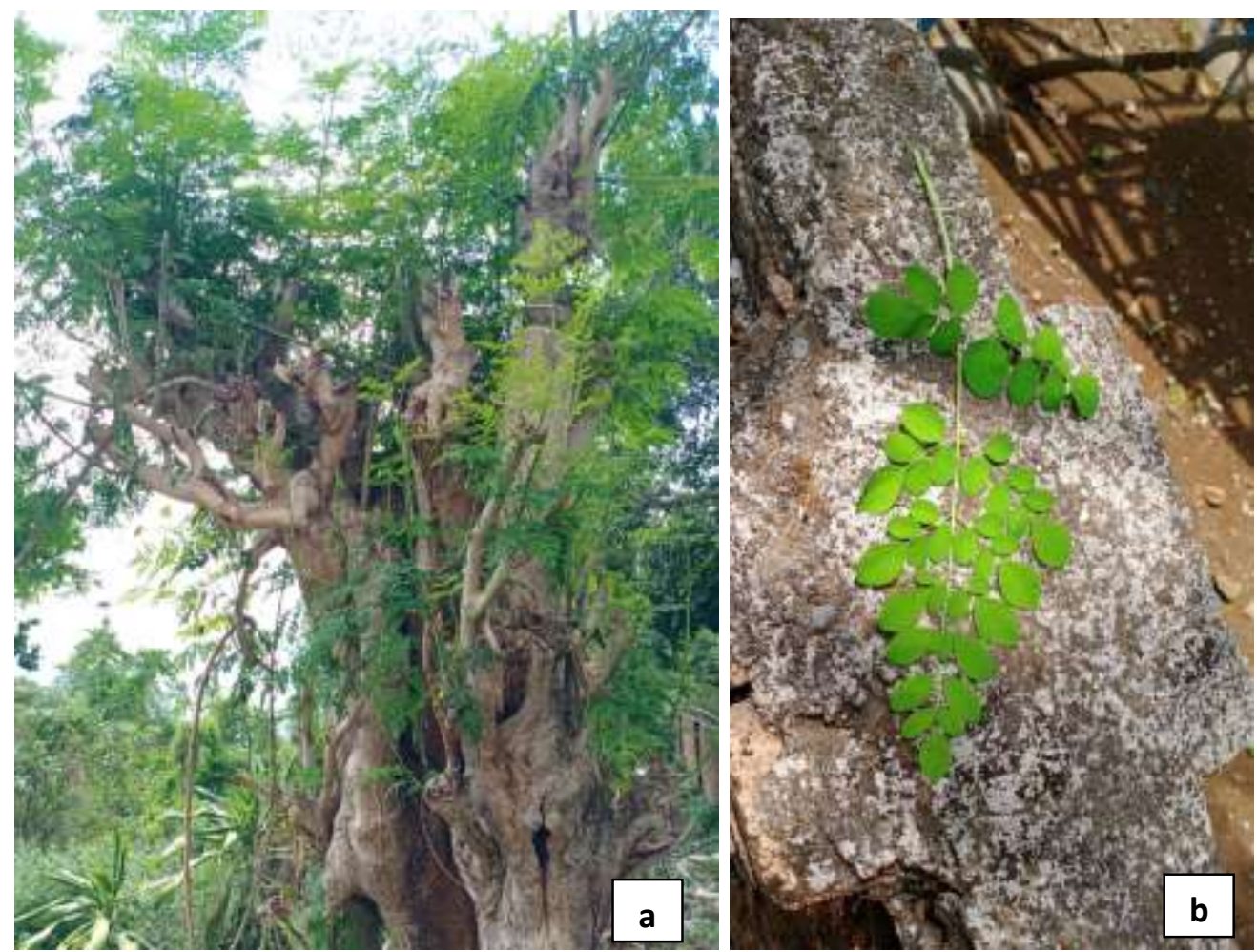

Gambar 1. Perawakan Moringa oleifera (a); Daun Moringa oleifera (b)

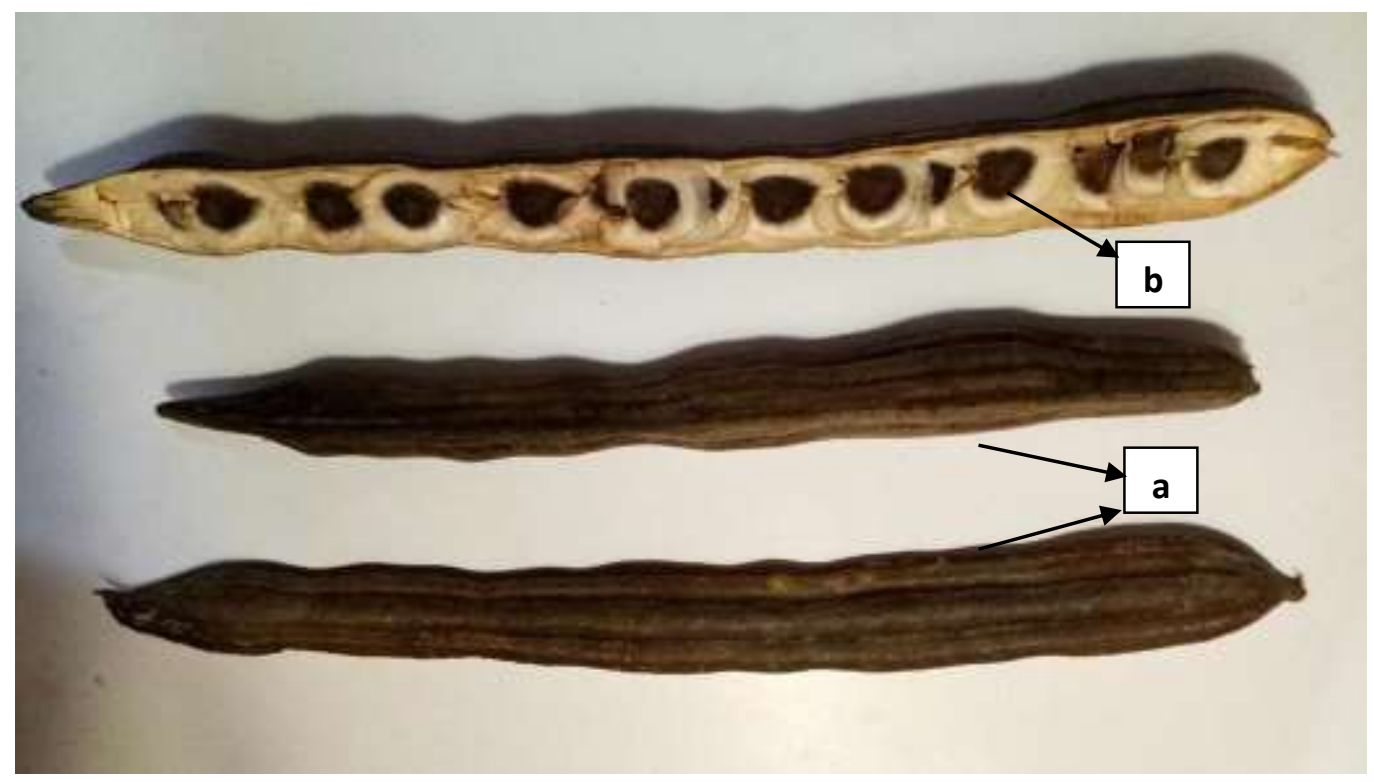

Gambar 2. Polong (a) dan biji (b) Moringa oleifera

Bunga MO berbentuk segitiga, berwarna putih kekuningan dan memiliki tudung pelepah berwarna hijau. Bunga memiliki aroma dan mekar sepanjang tahun. Polong MO berbentuk segitiga yang berukuran 20-60 cm, berwarna hijau saat muda dan berubah menjadi cokelat. Biji MO berwarna cokelat kehitaman yang berbentuk bulat (Gambar 2) (Winarno, 2018). 


\section{Bioaktivitas}

Bagian dari MO yang biasanya dimanfaatkan baik sebagai pangan dan obat tradisional adalah adalah daun (Price, 1985; Jain et al., 2010; Abalaka et al., 2012; Thirumalai et al., 2012), bunga (Price, 1985; Singh, et al.; 2015), kulit kayu (Balakrishnan et al., 2009), biji (Aderinola, 2019; Price, 1985), polong, kayu dan akar (Price, 1985). Semua bagian dari MO memiliki kandungan senyawa sekunder yang sangat bermanfaat. Daun MO mengandung alkaloid, flavonoid, saponin dan tannin (Abalaka et al., 2012). Bunga MO mengandung sukrosa, alkaloid, asam amino dan flavonoid seperti rhamnetin, isoquercitrin dan kaempferitrin (Pramanik \& Islam, 1998; Siddhuraju \& Becker, 2003). Biji MO mengandung benzylglucosinolate (Dayrit et al., 1990; Anwar \& Bhanger, 2003). Beberapa bioaktivitas MO adalah antibiotik, antitripanosomal, antiulkus, hipotensif, antiinlamasi (Fahey 2005; Chumark et al. 2007). Berikut di bawah ini beberapa senyawa bioaktivitas yang dibahas dalam artikel ini

\subsection{Antimikroba}

Daun, biji, minyak, bunga, akar dan kulit kayu dari MO secara ilmiah terbukti mengandung antimikroba (Fahey, 2005).

Data etnobotani mencatat bahwa masyarakat memanfaatkan daun MO sebagai anti jamur dengan cara menggosoknya ke kulit yang diserang jamur (Krisnadi, 2015). Kandungan flavonoid, saponin, triterpenoid dan tannin pada daun MO dapat menghambat pertumbuhan Streptococcus mutans, Malassezia furfur (Kiptiyah, 2008; Raharjo et al., 2012).

Penelitian Abalaka et al. (2012), membuktikan daun MO mengandung alkaloid, flavonoid dan saponin yang dapat menghambat bakteri Escherichia coli dan Salmonella typhi. Ekstrak daun MO mempunyai aktivitas antibakteri terhadap Staphylococcus aureus (Agustie \& Samsumaharto, 2013; Fouad et al., 2019). Pengujian konsentrasi ekstrak daun kelor $75 \%$ mempunyai daya hambat paling besar terhadap pertumbuhan bakteri Staphylococcus aureus daripada konsentrasi $25 \%$ dan 50\% dimana semakin besar konsentrasi ekstrak daun MO maka bertambah besar pula aktivitas hambatannya. Penelitian Fouad et al. (2019) juga menunjukkan bahwa daun MO menghambat bakteri Corynebacterium pseudotuberculosis secara efektif.

\subsection{Antioksidan}

Antioksidan merupakan zat yang dapat menghambat reaksi oksidasi akibat radikal bebas (Gutteridge \& Halliwell, 1999; Pujiastuti \& Saputri, 2019). Saat ini kebutuhan antioksidan alami diminati karena antioksidan sintetik memiliki efek samping, misalnya alergi, asma, peradangan, sakit kepala, penurunan 
kesadaran, gangguan pada mata, dan perut (Sharmila et al., 2016). Antioksidan bekerja sebagai penetral radikal bebas dengan mendonorkan electron dan mereduksi ion logam. Senyawa fenolik dan flavonoid berfungsi sebagai antioksidan karena memiliki gugus hidroksil yang dapat mendonorkan Hidrogen sehingga dapat menetralkan radikal bebas. MO memiliki kandungan flavonoid dan fenolik yang merupakan penunjuk adanya antioksidan.

Metode Diphenyl picryl hydrazine (DPPH) menunjukkan bahwa aktivitas antioksidan pada daun MO lebih kecil dibandingkan dengan vitamin C (Yuliani \& Dienina, 2015). Diperkirakan MO mengandung 46 antioksidan dan merupakan sumber antioksidan alami yang sangat baik untuk tubuh manusia. Antioksidan utama yang terkandung pada MO adalah quercetin, kaempferol, beta-sitosterol, caffeoylquinic dan zeatin. Kandungan antioksidan tersebut akan lebih baik bekerja jika digabungkan dengan beberapa vitamin dan mineral lain yang sudah tersedia sekaligus pada MO (Dhakar et al., 2011). Konsumsi 1,5 sendok the daun MO sertiap hari selama tiga bulan dilaporkan dapat meningkatkan kadar antioksidan dalam darah pada wanita (Winarno, 2018).

Pengujian kandungan fenolik pada MO dapat dilakukan dengan metode FolinCiocalteu (Singleton \& Rossi, 1965). Toripah et al. (2014) melakukan pengujian kandungan fenolik pada $0,1 \mathrm{ml}$ ekstrak daun MO dengan konsentrasi 10, 50, 100, 150 dan 200 ppm. Hasilnya menunjukkan kandungan senyawa fenolik terdapat pada daun MO sebanyak 126,52 pada konsntrasi 200 ppm.

\subsection{Pencegahan malnutrisi}

Kandungan gizi yang dimiliki MO dapat melawan masalah malnutrisi. Konsumsi MO banyak dilakukan di negaranegara berkembang khususnya memeperbaiki gizi bayi dan ibu yang menyusui. Biasanya MO dikonsumsi sebagai sayuran, yaitu polong dan daun. Daun MO merupakan sayuran prenial tropis yang memiliki sumber protein terbaik (Dhakar et al., 2019). Masih menurut Dhakar et al. (2019), polong muda MO dapat dikonsumsi segar (salad, acar) atau dimasak, sedangkan polong yang matang biasanya digoreng. Polong MO dapat diolah untuk mengasilkan minyak dimana kandungan gizinya sama dengan minyak zaitun. Bunga MO dapat dikonsumsi dengan pangan lainnya dalam keadaan segar (mentah) atau digoreng karena mengandung potassium dan kalsium.

Kelor mengandung protein dan asam amino yang sangat baik dibandingkan dengan kacang kedelai. Protein ini sangat baik untuk tubuh bahkan ketika seseorang tidak mendapatkan asupan protein hewani. Selain itu MO mengandung arginin dan histidin yang merupakan asam amino yang 
sangat baik untuk perkembangan bayi (Dhakar et al., 2011). Selain itu MO mengandung asam lemak yang baik untuk kesehatan yaitu omega-3 dan omega-6 (Dhakar et al., 2011). Daun MO mengandung witamin dan mineral yang baik untuk tubuh. Vitamin A, B1, B2, B3, kalsium, kalori, karbohidrat, tembaga, lemak, serat, besi, magnesium, phosphor, potassium, protein dan seng pada daun MO akan lebih banyak diserap tubuh jika dikonsumsi dalam keadaan kering sedangkan vitamin $\mathrm{C}$ sebaliknya (Abrams et al., 1993).

\subsection{Antikanker}

Salah satu penyakit yang menyebabkan angka kematian adalah kanker. Prevalensi kanker di Indonesia mencapai 1,79 per 1000 penduduk dimana prevalensi tiga tertinggi ada di Yogyakarta yaitu sebesar 4,86 per 1000 penduduk, Sumatra Barat 2,47 dan Gorontalo 2,44 (Badan Penelitian dan Pengembangan Kesehatan, 2019). Saat ini banyak penelitian yang bertujuan mencari senyawa antikanker yang tidak hanya membunuh sel kanker tetapi juga dapat mengurangi efek samping misalnya menghambat proliferasi, menginduksi apoptosis, menekan angiogenesis, menghambat invesivitas, menghambat metastasis, dan memperkuat kemoterapi (Al-Snafi, 1999; Al-Snafi et al., 2011; Al-Snafi, 2014; Al-Snafi, 2015; AlSnafi et al., 2015; Al-Snafi, 2016, Al-Snafi,
2016). Salah satu tumbuhan yang dapat dijadikan sumber anti kanker adalah MO.

Daun MO memiliki aktivitas antiproliferative pada beberapa sel kanker yaitu sel kanker hati HepG2, sel kanker paru A549, sel kanker kolon Caco-2 dan sel kanker payudara MDA-MB-231, dan sel kanker payudara T47D (Apriani et al., 2019). Hasil penelitian menunjukkan bahwa ekstrak daun MO memiliki efek sitotoksisitas terhadap sel kanker serviks dengan nilai IC50 sebesar $669,19 \mu \mathrm{g} / \mathrm{ml}$ dan menginduksi apoptosis pada sel kanker serviks (Ahimsa, 2014). Penelitian Andjani et al. (2016) juga membuktikan bahwa daun MO dapat menurunkan aktivitas cell line kanker payudara MCF-7.

Selain flavonoid, beberapa bahan aktif yang menyebabkan MO memiliki kandungan anti kanker adalah isothiocyanates, benzyl carbamate, niazimicin dan beta-sitosterol pada daun dan biji MO yang menyebabkan MO merupakan bahan alami anti kanker glucosinolates and isothiocyanates, betasitosterol, glycerol-1-(9-octadecanoate), 3O-(6'-O-oleoyl-beta-D-glucopyranosyl), beta-sitosterol dan beta-sitosterol-3-O-betaD-glucopyranoside (Berawi et al., 2019). Selain itu kandungan tersebut dapat mengurangi efek kanker.

\subsection{Antidiabetes}

Diabetes mellitus terjadi karena adanya hiperglikemia dan gangguan 
metabolisme karbohidrat, lemak, dan protein yang dihubungkan dengan kekurangan secara absolut atau relatif dari kerja dan atau sekresi (Fatimah, 2015). Prevalensi diabetes di Indonesia mencapai 1,5\% dimana prevalensi dua tertinggi ada di Jakarta yaitu sebesar 2,6\% dan Yogyakarta sebesar 2,4\% (Badan Penelitian dan Pengembangan Kesehatan, 2019).

Beberapa antidiabetes umum yang digunakan saat ini memberikan efek samping misalnya insulin, sulfonilurea, biguanida, tiazolidinedion dan glinide (Berawi et al., 2019). Untuk itu dibutuhkan anti diabetes yang aman misalnya MO. Moringa oleifera merupakan salah satu tanaman yang dapat menjaga kestabilan kadar gula darah. Tidak adanya efek samping membuat $\mathrm{MO}$ aman bagi penderita diabetes tipe 1 dan 2. MO mengandung asam ascorbic yang membantu sekresi insulin (Dhakar et al., 2019). Mengonsumsi 7-gram daun kelor setiap hari selama tiga bulan dapat menurunkan kadar gula dara sebesar 13,5\% dan penambahan 50-gram daun kelor pada menu makanan pasien diabetes dapat mengurangi kenaikan gula darah sebesar 21\% (Winarno, 2018).

\section{KESIMPULAN}

Kelor (Moringa oleifera) dapat dimanfaatkan manusia sebagai bahan pangan dan obat tradisional. Pemanfaatan tersebut sangat bermanfaat untuk peningkatan kesehatan manusia saat ini karena Moringa oleifera memiliki beberapa potensi farmakologis sebagai anti mikroba, antioksidan, pencegahan malnutrisi, antikanker dan antidiabetes. Untuk pengembangan kualitas dan diversifikasi pengolahan Moringa oleifera perlu adanya penelitian lanjutan untuk mengungkap potensinya.

\section{DAFTAR PUSTAKA}

Abalaka ME, Daniyan SY, Oyeleke SB \& Adeyemo SO. 2012. The Antibacterial Evaluation of Moringa Oleifera Leaf Extracts on Selected Bacterial Pathogens. Journal of Microbiology Research, 2(2):1-4.

Abrams B, Duncan D \& Hertz Piccioto I. 1993. A prospective study of dietary intake and acquired immune deficiency syndrome in HIV seropositive homosexsual men. J Acquir Immune Defic Syndr, 8:949-58.

Adamu HM, Abayeh OJ, Agho MO, Abdullahi AL, Uba A, Dukku HU \& Wufem BM. 2005. An ethnobotanical survey of Bauchi State herbal plants and their antimicrobial activity. Journal of Ethnopharmacology, 99:1-4.

Aderinola TA, Alashi AM, Nwachukwu ID, Fagbemi TN, Enujiugha VN \& RM. 2019. Antihypertensive and Antioxidant Properties of Moringa Oleifera Seed Enzymatic Protein Hydrolysate and Ultrafiltration Fractions. Current Topics in Nutraceutical Research, 17(4):437444.

Agustie AWD \& Samsumaharto RA. 2013. Uji aktivitas antibakteri ekstrak maserasi daun kelor (Moringa oleifera Lamk) terhadap bakteri Staphylococcus aureus. Biomedika, 6(2):14-19. 
Ahimsa GK. 2014. Aktivitas antikanker ekstrak air daun kelor (Moringa oleifer L.) terhadap cell line kenker serviks hela dengan uji sitotoksisitas, apoptosis dan jalur induksi apoptosis berdasarkan ekspresi gen P53. Skripsi. Indonesia: Universitas Gadjah Mada.

Al-Snafi AE, Nahi Y. Yaseen, \& Moslim Mohsin Al Shatry. 2015. Anticancer effects of sodium valproate. International Journal of Pharm Tech Research, 7(2), 291-297.

Al-Snafi AE, Raad M. Hanaon, Nahi Y. Yaseen, \& Wathq S. Abdul alhussain. 2011. Study the anticancer activity of plant phenolic compounds. Iraqi Journal of Cancer \& Medical Genetics, 4(2), 66-71.

Al-Snafi AE. 1999. The Methods followed by Arabic physicians for treatment of cancer 4th Arabic conf. of Medicinal plants. Yemen: Thamar Univ.

Al-Snafi AE. 2014. Anticancer effects of cimetidine. World J Pharm Sci, 2(4), 397-403.

Al-Snafi AE. 2015. Therapeutic properties of medicinal plants: a review of plants with anticancer activity (part 1). International Journal of Pharmacy, 5(3), 104-124.

Al-Snafi AE. 2016. Medicinal plants with anticancer effects (part 2)- plant based review. Scholars Academic Journal Pharmacy, 5(5), 175-193.

Al-Snafi, AE. 2016. Pharmacological importance of Clitoria ternatea-A review. IOSR Journal of Pharmacy, 6:63-68.

Amaglo NK, Bennett RN, Curto RBL, Rosa EAS, Turco VL, Giuffrida A, Curto AL, Crea F \& Timpo GM. 2010. Profiling selected phytochemicals and nutrients in different tissues of the multipurpose tree Moringa oleifera L., grown in Ghana. Food Chemistry, 122(4):1047-1054.
Andjani N, Sujuti H \& Winarsih S. 2016. Efek ekstrak etanol daun kelor (Moringa oleifera) terhadap Nuclear Factor Kappa Beta (NF-kB) aktif dan apoptosis cell line kanker MCF-7. Majalah Kesehatan FKUB, 3(4):204-212.

Anwar F \& Bhanger MI. 2003. Analytical characterization of Moringa oleifera seed oil grown in temperate regions of Pakistan. Journal of Agricultural and Food Chemistry, 51:6558-6563.

Apriani R, Gaffar S \& Herlina T. 2019. Aktivitas Sitotoksik Fraksi Etil Asetat Daun Kelor (Moringa Oleifera) dan pengaruhnya Terhadap Induksi Apoptosis Pada Sel Kanker Payudara T47D. Farmako Bahari, 10(1):9-16.

Arora DS, Onsare JG \& Kaur H. 2013. Bioprospecting of Moringa (Moringaceae): Microbiological Perspective. Journal of Pharmacognosy and Phytochemistry, 1(6):193-215.

Awodele O, Oreagba IA, Odoma S, da Silva JAT \& Osunkalu VO. 2012. Toxicological evaluation of the aqueous leaf extract of Moringa oleifera Lam. (Moringaceae). Journal of Ethnopharmacology, 139:330-336.

Badan Penelitian dan Pengembangan Kesehatan. 2019. Laporan Nasional Riskesdas 2018. Kementrian Kesehatan Republik Indonesia: Badan Penelitian dan Pengembangan Kesehatan, 628 hal.

Bahriyah I, A Hayati \& H. Zayadi. 2015. Studi Etnobotani Tanaman Kelor (Moringa oleifera) di Desa Somber Kecamatan Tambelangan Kabupaten Sampang Madura. e-Jurnal Ilmiah BIOSAINTROPIS (BIOSCIENCETROPIC), 1(1):61-67.

Balakrishnan V, Prema P, Ravindran KC \& Robinson JP. 2009. Ethnobotanical studies among villagers from Dharapuram Taluk, Tamil Nadu, 
India. Global Journal of Pharmacology, 3(1):8-14.

Becker K. 2003. Moringa oleifera: An Underutilised with Amazing Versatility. Department of Aquaculture Systems and Animal Nutritions. Germany: University of Hohenheim.

Berawi KN, Wahyudo R \& Pratama AA. 2019. Potensi terapi Moringa oleifera (Kelor) pada penyakit degeneratif. JK Unila, 3(1):210-214.

Caceres A, Aviles O, Freire V, Giron LM \& Pacheco JG. 1991b. Moringa oleifera (Moringaceae): Ethnobotanical Studies in Guatemala. Economic Botany, 45(4):522-523.

Caceres A, Cabrera O, Morales O, Mollinedo P \& Mendia. 1991. Pharmacological properties of Moringa oleifera. 1: Preliminary screening for antimicrobial activity. Journal of Ethnopharmacology, 33:213-2I6.

Chumark P, P Khunawat, Y Sanvarinda, S Phornchirasilp, NP Morales, LP Ngam, P Ratanachamnong, S Srisawat \& KUS Pongrapeeporn. 2007. The in vitro and ex vitro antioxidant properties, hydrolipidaemic, and antiatherosclerotic activities of water extract of IMoringa oleifera Lam. Leaves. Journal Ethnopharmacol, 116:439-44-6.

Dayrit IM, Alcantar AD \& Villasenor IM. 1990. Studies on Moringa oleifera seeds, Part I. The antibiotic compound and its deactivation in aqueous solution. Philip $J$ Sci, 119:23-32.

Dhakar RC, Maurya SD, Pooniya BK, Bairwa1 N, Gupta M dan Sanwarmal. 2011. Moringa: The herbal gold to combat malnutrition. Chronicles of Young Scientists, 2(3):119-125.

Dillard CJ \& German JB. 2003. Phytochemicals: nutraceuticals and human health: A review. J Sci Food Agric, 80:1744-1756.

Fahey JW. 2005. Moringa oleifera: A Review of The Medical Evidence for Its Nutrional, Therapeutic, and Prophylatic Properties Part 1. Online at

http://www.tfljournal.org/article.php /20051201124931586 [diakses 6 Desember 2019].

Fatimah RN. 2015. Diabetes Melitus tipe 2. J Majority, 4(5):93-101.

Fouad EA, Elnaga ASMA \& Kandil MM. 2019. Antibacterial efficacy of Moringa oleifera leaf extract against pyogenic bacteria isolated from a dromedary camel (Camelus dromedarius) abscess. Veterinary World, 12:802-808.

Fuglie LJ. 2001. The miracle tree: Moringa oleifera: Natural nutrition for the tropics, (Church World Service, Dakar, 1999). pp 68. revised in 2001 and published as The Miracle Tree: The multiple attributes of Moringa, pp172.

Gutteridge JMC \& Barry Halliwell. 2000. Free radicals and antioxidants in the year 2000. A historical look to the future. Online at http://woodlab.ucdavis.edu/ETX214 /Halliwell_ROS_Review.pdf [diakses 5 Juni 2019].

Hardiyanthi F. 2015. Pemanfaatan aktivitas antioksidan ekstrak daun kelor (Moringa oleifera) dalam sediaan hand and body cream. Skripsi. Universitas Islam Negeri Syarif Hidayatullah: Jakarta. 121 hal.

Islam MK, Saha S, Mahmud I, Mohamad K, Awang K, Uddin SJ, Rahman MM \& Shilpi JA. 2014. An ethnobotanical study of medicinal plants used by tribal and native people of Madhupur forest area, Bangladesh. Journal of Ethnopharmacology 151:921-930.

Jain DL, Baheti AM, Jain SR \& Khandelwal KR. 2010. Use of medicinal plants among tribes in Satpuda region of Dhule and Jalgaon 
districts of Maharashtra-an ethnobotanical survey. Indian Journal of Traditional Knowledge, 9(1):152-157.

Kadir MF, Sayeed MSB, Shams T \& Mia MMK. 2012. Ethnobotanical survey of medicinal plants used by Bangladeshi traditional health practitioners in the management of diabetes mellitus. Journal of Ethnopharmacology, 144:605-611.

Kasolo JN, GS Bimeya, L Ojok, J Ochieng \& JW Okwal-okeng. 2010. Phytochemicals and uses of Moringa oleifer leaves in Ugandan Rural Communities. Journal of Medical Plant Research, 4(9):753-757.

Kholis N \& Hadi F. 2010. Pengujian bioassay biskuit balita yang disuplementasi konsentrat protein daun kelor (Moringa oleifera) pada model tikus malnutrisi. Jurnal Teknologi Pertanian, 11(3):144-151. Kiptiyah M. 2008. Antibacterial activity of Moringa oleifera leaves extract to the growth of Streptococcus mutans. Online at https://www.ncbi.nlm.nih.gov/pmc/a rticles/PMC5175503/ [diakses 21 Desember 2019].

Krisnadi AD. 2010. Kelor Super Nutrisi. Blora: Pusat Informasi dan Pengembangan Tanaman Kelor Indonesia.

Liyanti PR, Budhi S \& Yusro F. 2015. Studi etnobotani tumbuhan yang dimanfaatkan di Desa Pesaguan Kanan Kecamatan Matan Hilir Selatan Kabupaten Ketapang. Jurnal Hutan Lestari, 393: 421-433.

Mabberley DI. 1987. The Plant Book. New York: Columbia University Press, Cambridge.

Maroyi A. 2013. Traditional use of medicinal plants in south-central Zimbabwe: review and perspectives. Journal of Ethnobiology and Ethnomedicine, 9(31): 1-18.

Mutiara T, Harijono, Estiasih $\mathrm{T} \&$ Sriwahyuni E. 2012. Nutrient
Content of Kelor (Moringa Oleifera Lamk) Leaves Powder under Different Blanching Methods. Food and Public Health, 2(6): 296-300.

Oktafiani R. 2018. Etnobotani tumbuhan obat pada masyarakat Desa Rahtawu di Lereng Gunung Muria Kudus. Skripsi. Semarang: Universitas Islam Negeri Walisongo. 128 hal.

Olson ME. 2002. Combining data from DNA sequences and morphology for a phylogeny of Moringaceae (Brassicales). Syst.bot, 27:55-73.

Olson ME. 2002. Intergeneric relationships within the Caricaceae-Moringaceae clade (Brassicales), and potential morphological synapomorphies of the clade and its families. Int. $J . P l$. Sci, 163: 51-65.

Pramanik A \& Islam SS. 1998. Chemical investigation of aqueous extract of the mature and premature flowers of Moringa oleifera (Sajina) and structural studies of a polysaccharide isolated from its premature flowers. Indian J Chem, 37B:676-682.

Price ML. 1985. The moringa tree. Amerika Serikat: Echo Technical Note. 19 hal.

Pujiastuti E \& Rahma Sani Saputri. 2019. Pengarauh metode pengeringan terhadap aktivitas antioksidan ekstrak etanol buah parijoto (Medinilla speciose Blume). Cendekia Journal of Pharmacy STIKES Cendekia Utama Kudus, 3(1): 44-64.

Qoniah EW. 2014. Uji kadar protein dan uji organoleptic biscuit dengan ratio tepung terigu dan tepung daun kelor (Moringa oleifera) yang ditambahkan sari buah nanas (Ananas comosus). Skripsi. Universitas Islam Negeri Syarif Hidayatullah: Jakarta. 35 hal.

Raharjo B, Erwiyani AR \& Susana MASD. 2012. Uji aktivitas antijamur dan bioautografi ekstrak etanol daun kelor (Moringa oleifera Lamk.) terhadap Malassezia furfur. Skripsi. 
Semarang: Sekolah Tinggi Ilmu Kesehatan Ngudi Waluyo Ungaran.

Rollof A, Weisgerber H, Lang U \& Stimm B. 2009. Moringa oleifera LAM. Weinheim: WILEY-VCH Verlag $\mathrm{GmbH} \& \mathrm{Co}$. KgaA.

Saikia AP, Ryakala VK, Sharma P, Goswami P \& Bora U. 2006. Ethnobotany of medicinal plants used by Assamese people for various skin ailments and cosmetics. Journal of Ethnopharmacology, 106:149-157.

Sharmila G, Nikithaa VS, Ilaiyarasi S, Dhivyaa K, Rajasekar V, Kumar NM, Muthukumaran K \& Muthukumarana C. 2016. Ultrasound assisted extraction of total phenolics from Cassia auriculata leaves and evaluation of its antioxidant activities. Industrial Crops and Products 84:13-21.

Siddhuraju P \& Becker K. 2003. Antioxidant properties of various solvent extracts of total phenolic constituents from three different agroclimatic origins of drumstick tree (Moringa oleifera Lam.) leaves. Journal of Agricultural and Food Chemistry, 51:2144-2155.

Singh MK, Paul J, De T \& Chakraborti T. 2015. Bioactivity guided fractionation of Moringa oleifer Lam. Flower targeting Leishmania donovani. Indian Journal of Experimental Biology, 53:747-752.

Singleton VL \& Rossi Jr. JA. 1965. Colorimetry of total phenolics with phosphomolybdic-phosphotungstic acid reagents. Am. J. Enol. Vitic, 16 (3):144-158.

Sutrisno L. 2011. Efek pemberian ekstrak methanol daun kelor (Moringa oleifera) meningkatkan apoptosis pada sel epitel kolon tikus (Rattus norvegius) wistar yang diinduksi
7,12 Dimetilbenz $(\alpha)$ antrasen (DMBA). Skripsi. Malang: Universitas Brawijaya.

Thirumalai T, David BC, Sathiyaraj K, Senthilkumar B \& David E. 2012. Ethnobotanical Study of Antidiabetic medicinal plants used by the local people in Javadhu hills Tamilnadu, India. Asian Pacific Journal of Tropical Biomedicine, 12: 910-913.

Toripah SS, Abidjulu J \& Wehantouw F. 2014. Aktivitas antioksidan dan kandungan total fenolik ekstrak daun kelor (Moringa oleifera Lam.). Pharmacon jurnal Ilmiah Farmasi UNSRAT, 3(4):37-43.

Waldron KW, Parker ML \& Smith AC. 2003. Plant cell wall and food quality. A review. J. Sc. Food Technol, 2: 109 $-110$.

Winarno FG. 2018. Tanaman Kelor (Moringa oleifera) Nilai Gizi, Manfaat, dan Potensi Usaha. Jakarta: Gramedia Pustaka Utama. 110 hal.

Yabesh JEM, Prabhu S \& Vijayakumar S. 2014. An ethnobotanical study of medicinal plants used by traditional healers in silent valley of Kerala, India. Journal of Ethnopharmacology, 154:774-789.

Yetein MH, Houessou LG, Lougbegnon TO, Teka O \& Tente B. 2013. Ethnobotanical study of medicinal plants used for the treatment of malaria in plateau of Allada, Benin (West Africa). Journal of Ethnopharmacology, 146:154-163.

Yuliani NY \& DP Dienina. 2015. Uji aktivitas antioksidan infusa daun kelor (Moringa oleifera, Lamk) dengan metode 1,1diphenyl-2picrylhydrazyl (DPPH). Jurnal Info Kesehatan, 14(2):1060-1081. 